\title{
College English Ecological Teaching Model and Resource Construction under the Background of "Internet"
}

\author{
Yi Wang \\ Nanyang Institute of Technology, Henan, Nanyang, 473004
}

Keywords: Internet +; College English; Ecological Teaching Model; Resource Construction

\begin{abstract}
With the deepening of economic globalization, the traditional college English teaching model has been unable to meet the needs of contemporary college students in English learning. In view of the shortcomings of the previous teaching mode, we must construct the harmonious teaching mode of university English through the construction of network education resources. The article first briefly summarizes the theory of educational ecology, and then analyzes the shortcomings of the traditional college English teaching process, and in-depth study of the "Internet $+"$ under the background of college English ecological teaching model and resource construction.
\end{abstract}

\section{Introduction}

With the rapid development of network information technology and the deepening of college English teaching reform, the shortcomings of traditional college English teaching mode have been fully exposed, not only to combat the enthusiasm of college students to learn English, and lead to the loss of vitality of college English classroom. In order to improve the overall teaching quality of college English classroom, the teaching process should be based on the professional characteristics of students and the reality of life, the traditional classroom teaching and contemporary educational technology organically integrated, so that students towards personalized learning and independent learning direction. In the "Internet +" environment, the use of a variety of media resources to build ecological teaching class.

\section{Overview of Educational Ecology}

Educational ecology first appeared in 1976 in the American scholar Cremin Lawrence's "public education" in a book. The so-called ecological teaching specifically refers to the flexible use of the basic theory of educational ecology to explore the classroom ecosystem among the behavior of the relationship between them, and their dynamic interaction with each other or the environment. Educational ecology belongs to the category of interdisciplinary. The factors in the ecological classroom mainly cover the main factors, the environmental factors and the non-physical factors. These three factors are interdependent and mutually restrictive, and any factors may change will affect the classroom teaching [1].

\section{The Defects of Traditional College English Teaching Process}

Teaching Content and the Actual Needs of Society Run Counter. In the process of traditional college English teaching, teachers find that college students are difficult to apply the phenomenon, that is, in the English classroom mastery of English knowledge cannot be effectively used in real life, do not meet the actual needs of contemporary society. Moreover, many of the daily needs of the vocabulary, phrases and common sentences, the course content is not involved. This led to a lot of college students on English learning gradually had a sense of boredom, and even appeared in the wrong attitude of learning. 
Teaching Methods Are Backward and Do Not Take Students as the Main Body. At present, college English teaching methods are extremely backward, most of the teaching model for the "five line", that is, teachers - blackboard - projection screen - recording equipment. Classroom teaching is still a teacher as the center, the implementation of "full house irrigation" type of teaching, basically no interaction between teachers and students. Even if there is a small amount of interaction, it is only a single model where the teacher asks the student to ask the student to answer. And many college English teachers are overly dependent on the Internet and teaching materials, the interaction between teachers and students into a picture display, rich screen to replace the teachers and students close communication, teachers will lose the opportunity to master the quality of student learning.

Excessive Emphasis on Memory and Evaluation Methods Are Less Scientific. In the traditional college English course teaching, the evaluation of college students' English level is grammar rules proficiency and word memory. In the test, in order to alleviate the pressure of teachers, will be appropriate to reduce the total amount of subjective questions, just test the memory of the objective problem, this neglect of the actual application level of students and evaluation ability to enhance the practice is clearly unscientific, because the ultimate goal of learning English is to apply to the reality of life. This ignores the concept of student learning ability training, and even spread to the English level examination and graduate examination, "high score low energy" phenomenon is becoming increasingly serious [2].

\section{College English Ecological Teaching Model and Resource Construction Analysis under the Background of "Internet +" Environment}

Form the "Student-Centered" Ecological Teaching Philosophy. The teaching and research group function fully play out in the "Internet + " in the background to actively build eco-college English teaching. Teachers should actively participate in the investigation and study, with other teachers to explore and improve the teaching strategy. To create a "humanistic guide, self-learning" modern learning links, establish a "student-centered" ecological teaching philosophy give full play to the potential of students.

Lesson preparation ecology. It is the primary task to realize the teaching of ecology and update teachers. In the "Internet +" background, all kinds of resource structure are constantly changing, so teachers in the lesson to continue to innovate ideas, teaching content and teaching methods. When students through the Internet to self-study, it will produce a deep level of learning needs, which is the teacher should update the teaching resources to meet the specific needs of learning. Preparation lesson takes the syllabus as the basis, from the overall grasp of teaching content, teaching and research groups as a unit, through the exchange of communication to establish the various levels of professional teaching model.

Classroom ecology. College English ecological teaching is the core of communication teaching, pay attention to the communication between teachers and students, rather than the knowledge of the transfer. Teachers and students should communicate in an equal environment to learn, teachers to show their own knowledge and experience, students to clarify their own experience and ideas, enrich the teaching content, build a flexible personalized ecological classroom, so that college English teaching and knowledge to build a development of the ecological process of change. In addition, teachers can make full use of the Internet, creating interesting teaching situations, to stimulate students' enthusiasm for learning.

Ecological Construction of Teaching Resources. College English ecological teaching in addition to the impact of teachers and students, but also by the material factors and mental factors, these three factors will be mutual constraints, mutual influence. The so-called teaching resources specifically refers to all the factors that help the curriculum goals, in addition to teaching materials, teaching facilities, networks and libraries and other material resources, but also covers teachers and students, parents and social members and other human resources. As the main body of classroom teaching, students will be subject to the teaching environment and material factors in depth. In the context of "Internet +", through the construction of ecological teaching resources, college English can effectively achieve a comprehensive teaching and learning, college students can be flexible use 
of resources to actively carry out self-learning. With the students actively participate in teaching activities, teachers and students to share the opportunity to increase teaching resources, teachers and students will be more frequent interaction, classroom learning will be more warm and harmonious.

The Diversification of Teaching Patterns. In 2007, the "College English Teaching Requirements" made it clear that the universities must change the teaching model based on teachers as soon as possible, make flexible use of high-end network information technology, build a rich computer network courses for college students to create quality Language learning atmosphere. In the context of "Internet +", college English teaching will not be limited by time and space, and can move towards personalized and independent learning. In the use of network information technology on the basis of, must not ignore the advantages of traditional classroom teaching. For example, college English is divided into reading and writing and audiovisual two parts, the former use of teacher-based teaching, multimedia technology, supplemented by the teaching methods, which can let college students in the computer room to start their own learning, with English teachers face to face counseling while playing the leading role of teachers at the same time, enhance the autonomy of college students learning ability.

Moreover, the ecological teaching model of college English is not only reflected in the reasonable layout of teaching mode, but also needs to realize the adaptability of various teaching modes, respect the difference of teaching group and choose the appropriate teaching content.

Use Ecological Teaching Evaluation Methods. In the environment of "Internet +", the ecological teaching of college English should adopt the combination of formative assessment and final evaluation. Formative assessment is a process and developmental assessment carried out in college English teaching. It mainly covers several major parts of student self-evaluation, evaluation and evaluation, and can usually use classroom activity record, network autonomous learning record, growth Archives and interviews and other forms of diversity, but also need to evaluate the emotional will, personality and other non-cognitive factors. Detailed records and effective supervision of the student's learning process, the students learn very helpful. The final assessment is a summary of the nature of the assessment, mainly the final exam and the level of test. This examination evaluates the actual use of English students' ability, a comprehensive study of reading and writing to listen to the ability to hear. Under the background of "Internet + " with rapid development of information technology, we should abandon the traditional single evaluation method, promote the ecological balance of college English classroom teaching and realize the comprehensive development of the individual through the characteristics of Internet information sharing [3].

\section{Conclusion}

In summary, in the context of "Internet +", the new era of college English teaching put forward higher requirements. The traditional college English teaching mode is prevalent, such as teaching content and social practical requirements do not match, teaching methods are backward and not students as the main body, teaching evaluation methods and other disadvantages. Therefore, in order to improve the overall teaching quality, the college English classroom must establish a unified and harmonious ecological teaching mode, flexible use of Internet technology to change the English teacher's "one speech" phenomenon, the ecological theory into college English teaching to meet the practical needs of college students of the ecological teaching model.

\section{References}

[1] Tang Xinxin. Information-based context of college English ecological teaching model analysis and construction[J]. Journal of Changchun Normal University (Natural Science Edition), 2016, 35 (3): 174-176.

[2] Wang Yan. Innovative classes in English "ecological" teaching model review [J]. Reading and writing (Education and Education), 2015, 12 (7): 20,23. 
[3] Jiang Bingbing, Guo Ming, Zhang Ruixia, etc. Based on ESP theory "language + professional" university English ecological teaching model construction [J]. Jiamusi University Social Science, 2014, 32 (3): 171-172. 